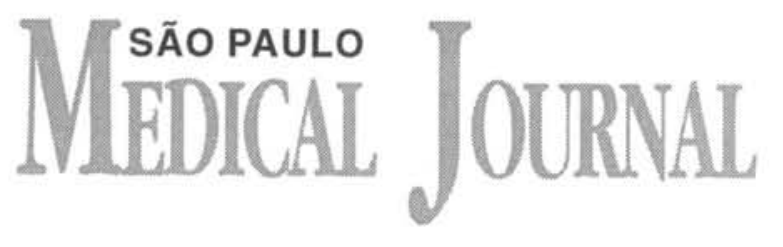

\title{
The undetermined form of Chagas' heart disease: concept and forensic implications
}

\author{
Heart Institute, Hospital das Clínicas da Faculdade \\ de Medicina da Universidade de São Paulo - São Paulo, Brazil
}

\begin{abstract}
The undetermined form of Chagas' disease is diagnosed in asymptomatic subjects with a positive blood test for Chagas' disease, normal resting electrocardiogram, chest X-ray, barium esophageal and large bowel radiological studies. Other investigation methods are not recommended for identification of other organs damage lesions in this phase of the disease. When other methods of investigation were employed, cardiac and digestive abnormalities of small magnitude were detected without prognostic implications. These findings do not warrant frequent examinations of patients with undetermined form of the disease except for the electrocardiogram or if the patients report other clinical manifestations. The benign course of the disease does not preclude ability to work and the subjects should be considered apt for work in any profession.
\end{abstract}

UNITERMS: Chagas' disease.

$\mathrm{T}$ The undetermined form of the Chagas' disease was initially described by Carlos Chagas who had recognized it as an clinical entity. He characterized the undetermined form as apparently normal individuals who behaved like "potential cardiac disease patients" (2). Later, Laranja et al. would define this entity as a "laboratorial form" (10). This "laboratorial form" included

\author{
Address for correspondence: \\ Antonio Carlos Pereira Barretto \\ Instituto do Coração do Hospital das Clínicas da Faculdade \\ de Medicina da Universidade de São Paulo \\ Av. Dr. Enéas de Carvalho Aguiar 44 \\ São Paulo - SP - Brasil - CEP 054003-000
}

infected patients who with or without an acute phase would remain asymptomatic with a marked Chagas' disease positive reaction for many years or even for the entire life.

The undetermined form of the Chagas' Disease (UCD) has been defined as a condition in which the patients show essentially a positive serum reaction without any digestive or cardiac clinical manifestations. More recently, on the basis of the definition conceived during the First Research Meeting Applied to Chagas' Disease, more than the absence of clinical manifestations, the patient must have a normal resting electrocardiogram, and unremarkable heart, esophageal and large bowel radiological studies (20). The number of undetermined Chagas' disease subjects is not entirely known. Epidemiological data estimate 5 to 6 millions of Brazilians with UCD (5). In Latin America, more than 20 million infected people is predicted. Very little research was done 
on UCD for a long time. However, its high prevalence in endemic zones (about $50 \%$ of the population), make us believe that nearly 3 million people exist nowadays in Brazil with UCD (3). In the last few years, the authors have observed a growing interest in the understanding of UCD. This is specially due to the emergence of new research tools. With these tools, it is possible to show the presence of cardiac and digestive involvement in most of cases. These new findings stir up doubts about what is the undetermined form of the Chagas' disease. It also raises doubts about the proper nomenclature to be employed in Chagas' disease, about the manners to conduct investigations into it. Furthermore, it produces doubts about the correct medical conduct to be adopted and about its medical laboratorial features. The definition of UCD given above is based on acknowledged arbitrary conditions which are reasonable for its definition.

Experience has demonstrated, though, that certain imprecise points turn into even less precise certain already inexact limits.

Not uncommonly, tolerant electrocardiogram interpretations must be considered, as well as the absence of large bowels radiological studies. These differences could contribute for the eventful finding of marked abnormalities through the use of sophisticated investigation methods in individuals with a doubtful and imprecise characterization of Chagas' disease's phase. The status of our research group knowledge shows undoubtedly that people with UCD are not completely normal. The countless number of laboratorial tests employed nowadays to determine abnormalities in heart and digestive tract studies allows the verification that a variable percentage of individuals present changes in each one of the employed methods. Although showing an unremarkable electrocardiogram, a simple vectorcardiographic study recognizes changes in most patients with $\operatorname{UCD}(15,19)$. Most of these changes are not specific. However, about one third of the subjects shows initial changes like those changes observed in the chronic phase. These changes being, for instance, conduction disturbances and inactive electric areas (19). Echocardiographic studies show normal values in all researched patients. However, when compared with a group of normal subjects, the dimensions of the heart chambers, although within the normal range, these dimensions were larger in the carriers of the disease. This is suggestive of an initial damage to the heart chambers $(4,19)$. The bi-dimentional echocardiography studies allow the visualization of the entire heart chambers. These studies have confirmed a normal global cardiac performance and the verification of regional contractibility abnormalities with the predominance of apex hypokinesia $(4,19)$. The presence of inflammatory changes in the myocardium may be investigated in a non-invasive way by means of the technetium-labeled pyrophosphate uptake test or with the gallium uptake test $(7,19)$. The latter shows a diagnostic yield of $100 \%$ of the investigated cases. In the stress test, depression of the ST segment, the presence of arrhythmias and chronotropic incompetence was observed in a variable rate. In our experience, the stress test was abnormal in $72 \%$ of the cases $(9 \%=$ chronotropic incompetence; $50 \%$ $=$ failure to elevate the blood pressure above $40 \mathrm{mmHg}$ and $50 \%=$ arrhythmias) (19). The dynamic electrocardiography is truly the best method for evaluating the presence of heart arrhythmias. The current literature indicates a variable incidence rate of arrhythmias. However, it is important to give evidence that most of these studies did not include control groups $(16,19)$. When compared to a control group, the incidence of heart arrhythmias in UCD is slightly higher, but the arrhythmia is generally benign in nature (1). Angiographic studies were the first type of investigation method to demonstrate relevant changes related to the undetermined form of the Chagas' disease (6). The data was confirmed later (14). Variable rates of apex hypokinesia and even actual ventricular aneurysm were recorded. Finally, endomyocardial biopsy showed histological changes in $60 \%$ of the cases studied $(13,18)$. This rate of histological changes is similar to the rate found in those patients chronically affected by the disease. The difference is that the histological changes are significantly less remarkable. More recently, along with the histological changes, immunopathological changes were recorded in $100 \%$ of those subjects with confirmed heart failure and, more rarely, in the subjects with the undetermined form of the disease (8). All these data were obtained employing different research methods and showed that it is possible to identify, among subjects with the undetermined form of the Chagas' disease, those subjects who actually have heart damage. The same finding was identified concerning the presence of damage in other organs. Esophageal manometric studies showed an abnormal esophageal function in $100 \%$ of those subjects defined as being UCD (17). All these results bring forward detached interpretations. Each investigator shows a certain percentage of changes and concludes that, among those subjects included in the undetermined form, this rate of changes reflects the patients with cardiac disorders, discussing the investigation method's value in final characterization of myocardiopathy.

The authors do not consider this thinking correct, because it does not regard some of the disease's basic characteristics. If one analyzes such data along with the 
clinical spectrum of the classic chronic phase, perhaps one could understand them better. Chagas' disease is polymorphic, with varied presenting forms. For instance, one may recall that right bundle block is frequent, but is not present in $100 \%$ of the cases. This is the case with the presence of arrhythmias, apex aneurysm, megaesophagus, megacolon, among other findings. However, if a right bundle block positive reaction subject displays an unremarkable echocardiogram or hemodynamic study (which it is not rare), one could say at best that cardiac function is preserved. However, it is not possible to state on a definite basis that no cardiac damage is present because Chagas' disease is patently multiform in its presentations. Despite its uncertain usefulness, except for academic interest, broader clinic-laboratorial evaluations are necessary in the characterization of undetermined form. Various tests that take into account the multiple features of the Chagas' disease manifestations are employed for the characterization of UCD because of its characteristic polymorphic presentation. With that objective in mind, the authors employed several methods in the same individual (19). They were six tests: vectorcardiography, uni- and bi-dimentional echocardiography, radioisotope ventriculography, technetium pyrophosphate cardiac mapping, dynamic electrocardiography and stress test. As mentioned earlier, a variable percentage of patients presented changes in each of these methods. When they were analyzed together, the authors could observe that $100 \%$ of the positive serum reaction subjects presented at least one abnormal test. Additionally, most of the patients $(63 \%)$ displayed an abnormality in at least four out of the six tests performed. One may conclude that there is a systematic cardiac and esophageal damage in the undetermined form of Chagas' disease $(3,17,19)$. It is also patent that all the disorders detected by means of those tests enumerated above were always of small magnitude. It is even justifiable to state that in the undetermined form, the cardiac damage profile proves to be less severe, the cardiac damage proves to be polymorphic in fashion that is possible to be demonstrated only through multiple noninvasive methods. This cardiac damage is similar to the chronic form, but with an undetermined progression. One must be careful with the possible interpretation of this statement. The authors are concluding that every person with a positive serum reaction shows cardiac and esophageal damage. This statement is not new. Cardiac and esophageal damage was demonstrated in a necropsy study of positive serum reaction subjects dying from an accidental death. These subjects showed to have cardiac and esophageal changes (denervation) (11). This finding, now fully sustained, that all individuals with a positive serum reaction for Chagas' disease have cardiac damage has a further implication. It does not change the subjects' prognosis, which has repeatedly been proved to be favorable $(4,12)$. Longitudinal epidemiological studies in endemic zones indicated that about $5 \%$ of the infected patients started to present clinically demonstrable abnormalities every year. The survival rate studies of individuals with Chagas' disease showed that the survival rate in the UCD is similar to the normal healthy population (9). This clearly indicates that the concern for heart failure and sudden death must always be related to chronic form of Chagas' disease. Even with the demonstration of cardiac and esophageal involvement in those patients, the authors consider that the denomination "undetermined form" is the most correct. Although being truthfully a chronic form, the undetermined form has perhaps a lesser aggressive potential. It may also have an uncertain progression and clinical manifestations that are only possible to be recorded on a unequivocal basis through laboratory testing. The undetermined form of Chagas' disease still has several inaccurate and undetermined features. Should the caring physician submit undetermined form patients to multiple examinations and testing? The authors' impression is negative. There is no defense for that. The studies always showed mild damage. Survival is not influenced by the presence of organ damage (this has been well demonstrated in epidemiological studies and it has also been proved by the absence of dire progression reports in subjects with the undetermined form of the disease).

The authors are also against the idea that a positive serum reaction identifies potential cardiac patients, who could be abandoned or who could also need unrelenting investigations. Actually, similarly to what is happening today with AIDS blood tests, the authors think that routine blood tests for Chagas' disease should be prohibited. A positive result serves only to label people who in its majority, would be productive for society. Cardiac examinations with electrocardiography are the best way to identify cardiac patients, and not blood tests. In the undetermined form, the authors believe that the patient must receive a medical follow-up. The patient must always be informed about his or her disease's benign character. They should also be periodically submitted to an electrocardiograph study, which is considered the best laboratory test to indicate the likely progression of the disease. Other laboratory tests may be performed, under the caring physician's criteria. This further testing is generally performed for the study and evaluation of certain specific symptoms and complaints reported by the patient, as in other heart diseases. As it is well known, routine 
examinations in asymptomatic patients with benign diseases (as the undetermined form) usually increase the health care costs, without providing any additional useful information. The authors can not state that undetermined form subjects have a dire disease prognosis, specially for the occurrence of sudden death, heart failure, bundle blocks and arrhythmias. These features are characteristic of the classic chronic phase and the association of these features with the undetermined form state has not been properly demonstrated. On the contrary, it is not accurate to state, based of epidemiological studies, that these patients will someday be symptomatic. These studies show many cases remaining with the undetermined form for the entire life. Additionally, those subjects with the undetermined form who present a progression of the disease will display in its majority a low-grade compromise. Progression to a more malignant form of the disease is uncommon. At InCor, the follow-up of subjects with the undetermined form during nearly 15 years of its existence, has clearly demonstrated how absolutely correct the disease benignity concept is. On the basis of this data and on the basis of the data presented above, it seems clear to the authors how unfair it is the belief ascribed to subjects with the UCD who are considered incapable to work. However, it is interesting to notice that, perhaps because of the greater awareness about the clinical manifestations and progression in subjects with coronariopathy and valvopathy, many of these subjects are able to get a job with medical consent, whereas undetermined form subjects are not able to. This is because of the simple fact they have positive serum reactions, despite completely asymptomatic and with a benign disease. The notion about the undetermined form benignity must be more accepted by the medical community in a way that we can defend the subjects with it and no longer label them. According to the authors' idea, the undetermined form subjects should lead a perfectly normal life, without restrictions to any activity. As any human being, they must undergo medical testing only when they present any symptoms. Therefore, the UCD subjects do not have to undergo multiple periodic medical testing simply because they carry Chagas' disease.

\section{RESUMO}

A forma indeterminada deve ser caracterizada em doentes assintomáticos e reaçōes sorológicas para doença de Chagas positiva em portadores de eletrocardiograma de repouso normal e estudo radiológico de coração, esôfago e cólons normais. A utilização de outros métodos, nāo deve ser indicada na identificaçāo desta fase da doença.

O emprego de outros métodos de avaliaçäo identifica comprometimento cardíaco e esofágico em todos os pacientes, entretanto sempre de pequena magnitude, o que não modifica seu prognóstico benigno.

Estes dados năo justificam exames rotineiros, à exceçāo do eletrocardiograma, nos portadores de forma indeterminada, a não ser que manifestaçāo clínica os indique.

Pelas características benignas da doença, não se deve estigmatizar seus portadores, que deveriam poder trabalhar normalmente em qualquer profissão. 


\section{REFERENCES}

1. ALMEIDA, J.W.R.; YASUDA, M.A.S.; AMATO NETO, V. et al. - Estudo da forma indeterminada da doença de Chagas através da eletrocardiografia dinâmica. Rev Inst Med Trop São Paulo 24:222-7, 1982.

2. CHAGAS, C. - Processos patogênicos da tripanossomíase americana. Mem Inst Oswaldo Cruz 8:5-9, 1916.

3. COURA, J.R.; ABREU, L.L.; PEREIRA, J.B. et al. Morbilidade da doença de Chagas. IV Estudo longitudinal de dez anos em Pains e Iguatama, Minas Gerais, Brasil. Mem Inst Oswaldo Cruz 80:73-80, 1985.

4. CUNHA, C.L.P. - Estudo doppler ecocardiográfico evolutivo da função ventricular na forma indeterminada da doença de Chagas. Paraná, 1992 [Tese - Concurso Prof. Titular de Clínica Médica - Universidade Federal do Paraná].

5. DIAS, J.C.P.; DIAS, E. - A doença de Chagas. In: Ministério da Saúde - SUCAM Doença de Chagas. Texto de Apoio, Brasília, 1989. p.13-20.

6. GARZON, S.A.C.; LORGA, A.M.; FERREIRA, J.G.S. et al. - Cardiopatia chagásica sem sinais clínicos de cardiopatia. parte I. Arq Bras Cardiol 28:232-42, 1975.

7. GEORGI, M.C.; MENEGUETTI, J.C.; HIRONAKA, F.H. et al. - Quantificação de captação miocárdica de gálio 67 em pacientes portadores de doença de Chagas. Arq Bras Cardiol 45:132-7, 1985

8. HIGUCHI, M.; LOPES, E.A.; SALDANHA, L.B. et al. Immunopathologic studies in myocardial biopsies of patients with Chagas' disease and idiopathic cardiomyopathy. Rev Inst Med Trop São Paulo 28:87-90, 1986.

9. KLOETZEL, K. \& DIAS, J.C.P. - Mortality in Chagas' disease: life table for the period 1949-1967 in an unselected population. Rev Inst Med Trop São Paulo 10:5-8, 1968.
10. LARANJA, F,S. - Aspectos clínicos da moléstia de Chagas. Rev Bras Med 10:482-91, 1953.

11. LOPES, E.R.; CHAPADEIRO, E. \& ANDRADE, Z.A. Anatomia patológica de coração em chagásicos assintomáticos falecidos de modo violento. Mem Inst Oswaldo Cruz 76:189-97, 1981.

12. MACEDO, V. - Forma indeterminada da doença de Chagas. J Bras Med 38:34-40, 1980.

13. MADY, C.; BARRETTO, A.C.P.; STOLF, N. et al. - Biópsia endomiocárdica na forma indeterminada da doença de Chagas. Arq Bras Cardiol 36:387-90, 1981.

14. MADY, C.; MORAES, A.V.; GALIANO, N. et al. - Estudo hemodinâmico na forma indeterminada da doença de Chagas. Arq Bras Cardiol 38:271-7, 1982.

15. MADY, C.; PEREIRA BARRETTO, A.C.; MOFFA, P.J, et al. - O vetorcardiograma na forma indeterminada da doença de Chagas. Arq Bras Cardiol 44:83-7, 1985.

16. MARINS, N.; FLORES, A.P.; SEIXAS, T.N. et al. Electrocardiografia dinâmica em chagásicos na forma indeterminada ou sem cardiopatia aparente. Arq Bras Cardiol 39:203-8, 1982.

17. MORAES FILHO, J.P.; MORAES, T.A.B.P.P.; FELIX, V.N. et al. - Esophageal manometry and vectorcardiography study of asymptomatic patients with Chagas' disease. Rev Inst Med Trop São Paulo 30:406-10, 1988.

18. PEREIRA BARRETTO, A.C.; MADY, C.; ARTEAGAFERNANDEZ, E. et al. - Right ventricular endomyocardial biopsy in chronic Chagas' disease. Amer Heart J 111:30713, 1986.

19. PEREIRA BARRETTO, A.C.; SERRO AZUL, L.G.; MADY, C. et al. - Forma indeterminada da doença de Chagas - Uma doença polimórfica. Arq Bras Cardiol 55:347-53, 1990.

20. Primeira Reunião de Pesquisa Aplicada em Doença de Chagas - Validade do conceito da forma indeterminada. Rev Soc Bras Med Trop 46:46, 1985. 